\title{
Experience of pregnancy and maternity by adolescents/ young people born infected with HIV
}

\author{
Vivência da gestação e da maternidade por adolescentes/jovens que nasceram infectadas pelo HIV \\ Experiencia de embarazo y maternidad por adolescentes/jóvenes que nacieron infectados por el VIH
}

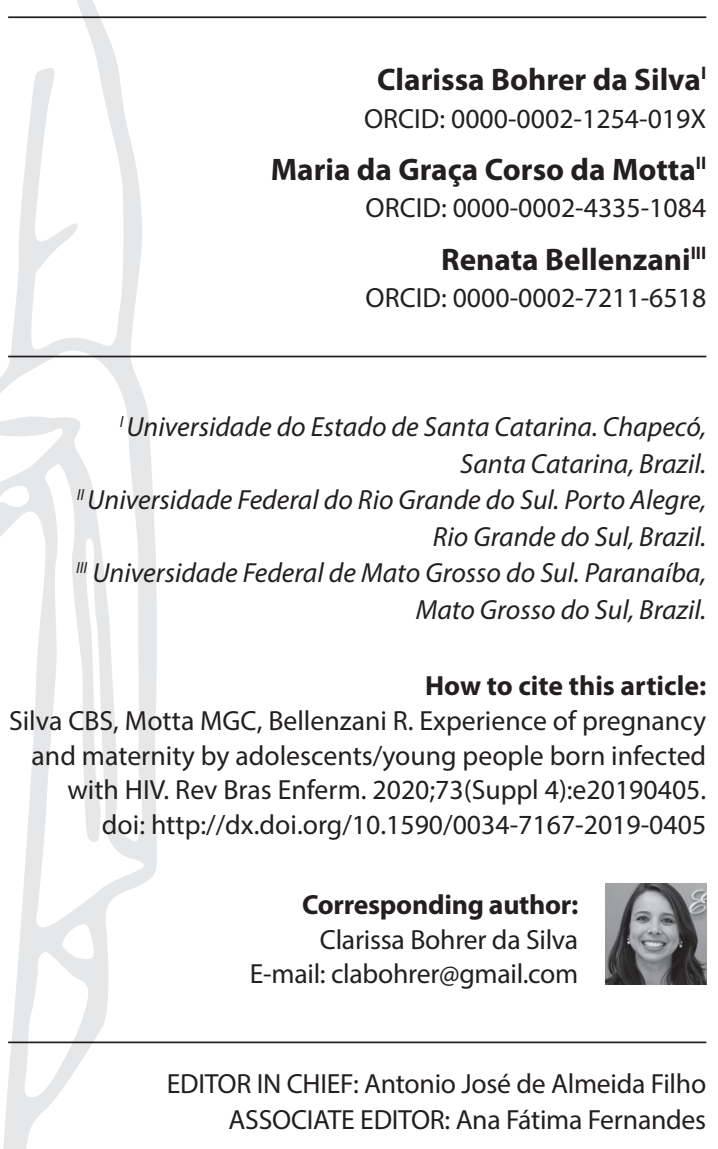

Submission: 07-26-2019
Approval: 03-18-2020

\begin{abstract}
Objective: to understand the experience of pregnancy and motherhood by adolescents/ young people who were born infected with HIV. Method: we carried out a qualitative study specialized in HIV service in Porto Alegre (RS/Brazil). Ten adolescents/young people were interviewed from June 2017 to March 2018. Thematic analysis was performed, using a vulnerability framework to reflect about unplanned pregnancy and its implications for care. Results: four categories were highlighted: Discovery of the ongoing pregnancy: ambivalent feelings towards seropositivity; Breaking the news of the pregnancy to partner, family and health professionals; Experience of childbirth and prophylaxis of vertical transmission of HIV; and Experience of motherhood: implications for life stories and future projects. Final considerations: the study contributes to addressing situations of vulnerability to the occurrence of unplanned pregnancy, showing the need for dialogical proposals that respect human rights in the production of comprehensive care and reproductive planning.

Descriptors: Adolescent Health; HIV; Pregnancy in Adolescence; Health Vulnerability; Nursing.
\end{abstract}

\section{RESUMO}

Objetivo: compreender a vivência da gestação e da maternidade por adolescentes/jovens que nasceram infectadas pelo HIV. Método: estudo qualitativo, realizado em serviço especializado em HIV de Porto Alegre (RS/Brasil). Entrevistaram-se 10 adolescentes/jovens, de junho de 2017 a março de 2018. Realizou-se análise temática, utilizando referencial de vulnerabilidade para refletir sobre a gestação sem planejamento e suas implicações no cuidado. Resultados: evidenciaram-se quatro categorias: Descoberta da gravidez em curso: sentimentos ambivalentes diante da soropositividade; Revelação da notícia da gestação ao parceiro, familiares e profissionais de saúde; Vivência do parto e da profilaxia da transmissão vertical do HIV; e Vivência da maternidade: implicações nas histórias de vida e projetos futuros. Considerações finais: o estudo contribui ao enfrentamento das situações de vulnerabilidades à ocorrência da gestação sem planejamento, apontando a necessidade de propostas dialógicas que respeitem os direitos humanos na produção do cuidado integral e planejamento reprodutivo.

Descritores: Saúde do Adolescente; HIV; Gravidez na Adolescência; Vulnerabilidade em Saúde; Enfermagem.

\section{RESUMEN}

Objetivo: comprender la experiencia del embarazo y la maternidad de adolescentes/jóvenes que nacieron infectados con $\mathrm{VIH}$. Métodos: estudio cualitativo, realizado en un servicio especializado en VIH en Porto Alegre (RS/Brasil). Se entrevistó a 10 adolescentes / jóvenes, de junio de 2017 a marzo de 2018. Se realizó un análisis temático, utilizando un marco de vulnerabilidad para reflexionar sobre el embarazo no planificado y sus implicaciones para la atención. Resultados: se destacaron cuatro categorías: descubrimiento del embarazo en curso: sentimientos ambivalentes hacia la seropositividad; Divulgación de noticias de embarazo a socios, familiares y profesionales de la salud; Experiencia de parto y profilaxis de la transmisión vertical del VIH; y Experiencia de la maternidad: implicaciones para historias de vida y proyectos futuros. Consideraciones finales: el estudio contribuye a enfrentar situaciones de vulnerabilidad a la ocurrencia de embarazo sin planificación, señalando la necesidad de propuestas dialógicas que respeten los derechos humanos en la producción de atención integral y planificación reproductiva.

Descriptores: Salud del Adolescente; VIH; Embarazo en Adolescencia; Vulnerabilidad en Salud; Enfermería. 


\section{INTRODUCTION}

The right to health care for women with HIV and the unborn child implies the State's obligation to ensure that motherhood does not bring risks to her health and that of others involved, both through Vertical Transmission (VT) and seronegative and seropositive partners ${ }^{(1)}$. The possibility of preventing HIV VT, with the prophylaxis strategies recommended by the Ministry of Health - among these the universal antiretroviral therapy in prenatal, delivery and for the exposed newborn; an indication of cesarean or vaginal delivery for pregnant women using antiretroviral and suppression of sustained viral load, if there is no indication for a cesarean for another reason; and replacement of breastfeeding with milk formulas - resulted in progress in the reproductive decisions of this population ${ }^{(2)}$.

At the beginning of the epidemic, HIV-infected women were discouraged from getting pregnant and strongly censored by the health team, which resulted in abortion or abandonment of treatment ${ }^{(3)}$. Social norms and stereotypes about the epidemic, represented by neglect and the lack of reproductive planning in the care of women with HIV, constitute obstacles to the exercise of reproductive rights ${ }^{(4)}$. Even today, health services, despite working adequately for the prevention of $\mathrm{VT}$, incur inattention to comprehensive care for women, especially regarding conceiving them as a person with rights, as the historical prioritization of fragmented care persists, that is, focused on the child at the expense of the woman ${ }^{(1)}$.

A study on reproductive decisions among women with HIV points out that the decision to have or not to have children does not depend on the serological condition ${ }^{(5)}$, highlighting that the experiences and meanings of motherhood in this context converge with those of women with high-risk pregnancies ${ }^{(6)}$. Currently, technical possibilities are available in health services for HIV-positive women who wish to get pregnant. In addition to the effectiveness of antiretroviral agents for reducing viral load, the offer of assisted reproduction is an option for HIV-positive or serodifferent couples (where one partner has HIV and the other does not have it $)^{(3)}$.

Understanding motherhood from the perspective of people infected with HIV is fundamental for a clearer analysis of a framework that, in terms of public policies, is approached in a simplistic and homogenizing way, not considering the secrecy and complexity of living with the virus in a society full of stigmas ${ }^{(1)}$. Adolescents/young people who were born infected with HIV experience even greater vulnerability to neglect/violation of these rights, either due to structural aspects such as the stigma of the disease, gender inequalities and because this age group is not sufficiently recognized, welcomed and listened to in health services. It is necessary to consider the sexual and reproductive health of young people living with HIV as an effective demand for care so that aspects that increase their vulnerability are managed with adequate resources, information, and support ${ }^{(7)}$. Especially in adolescents/young people who were born infected with HIV, in which there is a triple facticity, adolescence, pregnancy and chronic serological condition acquired in childhood, there is a possibility of (re)experiencing HIV VT. However, it still is a theme with a few basic studies.
In Brazil, from 2000 to June 2019, of the 125,144 pregnant women notified as infected with HIV, the age group between 20 and 24 years has the highest number of cases (27.8\%). Added to this, the worrying rate of HIV detection in pregnant women in the state of Rio Grande do Sul, especially the capital Porto Alegre, has remained above the national rate in recent years ${ }^{(8)}$. In this sense, this research originated as a demand from the health service of the city of study as a recognition of the experience of these adolescents/young people regarding pregnancy.

The experience of pregnancy and motherhood can be elucidated by articulating processes of synergistic construction both of exposure and protection against unplanned pregnancy, in the three dimensions of vulnerability (individual, social, and programmatic) ${ }^{(9)}$. They are mutually referred to help to understand the personal trajectories in which health outcomes occur, such as pregnancies. Hence, the vulnerability reference makes it possible to decode the circumstances and the meanings that pregnancy acquires in each personal trajectory, although on socially shared bases, therefore expressive of the conditions and experiences that configure the trajectories of life and care.

\section{OBJECTIVE}

To understand the experience of pregnancy and motherhood by adolescents/young people who were born infected with HIV.

\section{METHODS}

\section{Ethical aspects}

The research followed the ethical precepts provided for in Resolution 466/12, which guides the development of research with human beings. The Universidade Federal do Rio Grande do Sul's Research Ethics Committee approved the study and research setting institution. Adolescents/young people signed the Informed Consent Term (all were over 18 years of age). To guarantee anonymity, participants were identified by pre-established codes, which include the letter " $\mathrm{P}$ " out of participants, followed by Arabic numbers for cataloging the results.

\section{Type of study and theoretical framework}

This is a qualitative study inspired by social constructionist ${ }^{(9)}$ and the concept of vulnerability ${ }^{(9)}$, which underlies the Brazilian Framework of Vulnerability and Human Rights (Quadro da Vulnerabilidade e Direitos Humanos, abbreviated Quadro V\&DH). It aimed to explore the psychosocial dimension of the experience of pregnancy and motherhood in the life trajectories of adolescents/young people who were born with HIV. In this sense, the vulnerability framework helps to understand social aspects, especially stigma and/or discrimination, which, linked to programmatic aspects, have repercussions on insufficient access to information and appropriate health care, even in the face of ongoing pregnancies, which subsidize the full exercise of reproductive rights. The standardized checklist COREQ (Consolidated Criteria for Reporting Qualitative Research), which contains the consolidated criteria for qualitative research reports was used. 


\section{Study setting}

The study was carried out in a Specialized HIV Care Ambulatory Service in the city of Porto Alegre, RS, which was chosen because it constitutes a pioneer in the establishment of a line of the care in the city, being one of the reference services for care HIV-positive adolescents/young people. A multidisciplinary team is available: nurses, social workers, psychologists, infectious disease doctors, pediatricians, and gynecologists/obstetricians.

\section{Study participants}

The study participants were adolescents/young people who were born infected with HIV. The chronological delimitation for this phase used worldwide for statistical and political purposes is the age group between 15 and 24 years old ${ }^{(10)}$. Inclusion criteria considered adolescents (15 to 19 years old) or young people (20 to 24 years old) infected with HIV by VT, who got pregnant during adolescence or youth and were monitored at the health service study setting. Adolescents/young people who abandoned follow-up and died composed the exclusion criteria. The selection was carried out by convenience, with the approach of the largest number of adolescents/young people followed up at the service. They were invited on the day they had an appointment at the infectology clinic, including all those that met the inclusion/exclusion criteria, without using the saturation criterion. Of the 49 adolescents/young people who got pregnant and were followed up at the infectology service between 2013 and 2018, 13 were HIV positive due to VT, of which two did not meet the study criteria and one died, totaling 10 participants.

\section{Data collection}

On the day of the appointment, contact with participants was through the indication of health professionals. The approach took place, through an informal conversation, with a view to a relationship of empathy and trust between the participant and the researcher, a doctoral nurse with previous research experience with HIV adolescents. A private place was made available in the service for the development of the interviews, which took place in the period between June 2017 and March 2018. We used a semi-structured interview script composed of open-ended questions: how did pregnancy happen in your life? What was your health care during pregnancy? Do you think pregnancy/motherhood has brought you learning? Which one(s)? The duration of the interviews ranged from 30 to 90 minutes, being audio recorded and later transcribed.

Elaborating a script and conducting an individual semi-structured in-depth interview was inspired by the methodology of the scenes. This methodology consists of encouraging the interviewees to report their experiences in the form of construction of scenes of experiences, in terms of those who live it. It aims at the emergence of the repertoire of social conducts and practices regulated by intersubjectively shared socio-cultural settings. There is an emphasis on trying to access, through interviewer-interviewee dialogue, stigmatization, or those resulting from identity differences and social inequality, implying different possibilities of exercising rights in everyday experience ${ }^{(9)}$.

\section{Data analysis}

Thematic analysis ${ }^{(11)}$ was carried out in three phases: 1$)$ preanalysis, 2) exploration of the material and 3) treatment of results, inference and interpretation. The vulnerability reference ${ }^{(9)}$ was used to reflect on the occurrence of unplanned pregnancy and its implications for the care of HIV-infected adolescents/young people. Four main categories of analysis were identified in the set of transcribed material: Discovery of the ongoing pregnancy: ambivalent feelings towards seropositivity; Breaking the news of the pregnancy to partner, family and health professionals; Experience of childbirth and prophylaxis of HIV VT; and Experience of motherhood: implications for life stories and future projects.

\section{RESULTS}

Adolescents/young people were in the age group from 19 to 23 years old. The age at the time of the first pregnancy ranged from 14 to 21 years old. Most had only one pregnancy, two participants experienced two, and one three pregnancies. Of all the children born, only one was infected with HIV by VT. No partner was reported to be HIV-positive. Concerning education, two did not complete elementary school, six did not complete high school, two completed high school. Most of the reasons for dropping out of studies were pregnancy. As for color, eight adolescents/ young people considered themselves black/mixed-race. As for family income, the majority reported income below or equal to one thousand reais (Brazilian currency), five of which received assistance from government programs.

\section{Discovery of the ongoing pregnancy: ambivalent feelings towards seropositivity}

The moment of discovery of the outgoing pregnancy in the study is marked by apprehension about their presumptive signs and nervousness for what is to come. Most sought the health service on suspicion of pregnancy or due to the uncomfortable symptoms they had, without necessarily associating them with a possible pregnancy:

Ah, I was already suspicious, first menstruation, then you start feeling sick, wanting to eat different things [...] / took a blood test, I found out at 4 months [...]. (P3)

One day I found my foreign body [...] the doctor [...] asked for an abdominal exam and then I found out I was pregnant. (P9)

After discovering the pregnancy, adolescents/young people expressed the ambivalence of feelings with the news, to some extent not consciously expected, referring to surprise, nervousness, sadness, and joy. They have the fear of experiencing pregnancy due to HIV infection, but the others, the minority, feel concern due to age.

I think that if you don't plan a child, you don't live that. I was in a state of shock, I didn't expect [...] I was very young. (P1)

I was a little happy and a little sad. Because I was afraid of him [partner] having caught [HIV] and fear because of the child. (P5) 
After learning about pregnancy, all adolescents/young people referred to their seropositivity when they mentioned that they would have to be more careful, aiming at preventing VT:

I remembered HIV [...] but I knew I could prevent. (P5)

When I got pregnant, I just thought that I would have to take care of myself more [...] having to take the right medicine, that I couldn't fail. (P3)

Some young women reported feeling unprepared to deal with this situation due to their early age or due to the mother's previous negative experience of loss:

Horrible, I want to take the baby, because I didn't want to now. I was ending my life, so to speak, because I had not even finished school, I had just started working. (P3)

At first, I thought "I don't want to" [...] I wanted more leisure, going to parties, going to the mall, and when I found out, I thought I would no longer be able to do that. (P9)

Sadness, anger, all together, nothing was good. I soon remembered my mother [...] she was pregnant, the baby died and then she died too. [...] gave me despair. (P8)

Although they explained the possibility of inducing abortion, all interviewees went on with their ongoing pregnancies and also did not share possible experiences of induced abortion with other pregnancies with the interviewer.

\section{Breaking the news of the pregnancy to partner, family and health professionals}

The partner, in general, received the news of the pregnancy with happiness, but with fear because he was also young and had no previous experiences.

He was happy, but also in shock. It was very fast. (P1)

The relatives of the adolescents/young people, for the most part, received the news with concern, for considering an inappropriate time to have a child or for assessing some complexity involved in the experience of pregnancy in the context of HIV-seropositivity.

[family member] was not very supportive, said that what we did was not right, that it was too early to have a child, that we had to go to college. (P5)

She [mother] said "how are you going to take care of a child if you are no longer healthy to be able to generate a child? what if you die or if the baby dies at the time of delivery?". Then I started to cry and we didn't speak for a while. (P3)

Mostly, the adolescents/young people praised the attention received at the study health service from the confirmation of pregnancy. They felt welcomed and claimed to have received information about the changes resulting from the pregnancy and possible complications. However, after delivery, this contact reduced for routine health monitoring, with more spaced appointments.
They were super attentive to me, they showed that my medication would change during pregnancy, that my doctors would change [...] it was really cool [...] afterwards I didn't have as much contact. (P1)

\section{Experience of childbirth and prophylaxis of HIV Vertical Transmission}

Adolescents/young women described the moment of birth as exciting, but at the same time distressing, they say they do not know how it would happen. Most of them reported that health professionals first referred them to attempt a vaginal delivery, even though that was not their desire. One of the participants revealed that she had stopped, on her initiative, the use of antiretroviral drugs, to increase viral load and, thus, having justified and increased the chances of being able to perform a cesarean section.

It was going to be a normal birth because it is healthier for women. And as my disease was undetectable, they did not care much about it [...]. Except that I always told the doctor that I did not want a normal birth [...] was cesarean. (P1)

I was supposed to have had a normal delivery, but in the last month my viral load was a little high, so they opted for a cesarean section.I stopped taking medicine because I didn't want a normal birth. (P7)

It was induced normal delivery. [...] I did not expect [...] they told me that HIV-positive women could not have a normal delivery, I was quite scared, I did not know what it was like, I was prepared for cesarean section. (P10)

Concerning preventing HIVVT through prophylaxis, all adolescents/young people express the child's fear of becoming infected. As a motivation to engage in their care during pregnancy and after childbirth, they point out that they do not want their child to have to live with the infection and depend on continuous intake of antiretroviral agents, sometimes hidden from people living together.

It was good, it was great, I didn't want them to get [HIV], because I know what it's like to live with it. Depending on medicine is horrible. (P4)

To this end, some adolescents/young people referred to anchor themselves in the experience of other family members who managed to avoid VT or in the low probability of transmission if they comply with the prophylaxis recommendations.

I was afraid she would take it, so my husband said that if my mother made it with my brothers [avoid VT] / would also [make it]. (P5)

[...] my niece was negative and I don't want her [daughter] to be reactive. $(\mathrm{P} 10)$

At first, some interviewees reported difficulties in administering antiretroviral agents to the child also to reach a negative serological diagnosis. However, all reported feeling relief when they discovered their children's HIV seronegativity.

At first it was difficult to give medication because she spit [...]. It was a relief when I saw her undetectable exam, we take a weight off our back. (P5) 
The best thing that happened was hearing from the doctor that she did not have [HIV]. [...] I think there is no greater emotion for a mother. (P1)

I was proud of myself, I spoke to me "you are the best mother in the world". (P9)

The statements of two young women show concern about the risk of VT and imaginarily anticipate the future moment, meaning as tense, of a possible revelation of the positive diagnosis to the child:

I was afraid of passing it on to her, of her being with the same trauma that I was, I think "how am I going to tell my daughter something like this?"It was difficult for my mother to tell [...] then I took care of that a lot. (P3)

I think about her in the future, I don't know how she will react, she can judge me, I don't know if she would blame me. (P10)

One of the adolescents/young women reported not having received prophylaxis, as a result of abandoning their health care, which resulted in HIV VT for their daughter.

I didn't take [antiretroviral agents] for a long time, so I think she [daughter] got this [HIV-infected], because I didn't do prenatal care [...]. So, they thought that I don't know how to take care of myself. [...] tomorrow I have to go to the Guardian Council [...]. I was really wrong, I didn't come here, now I'm bothering. (P2)

\section{Experience of motherhood: implications for life stories and future projects}

Motherhood brought changes in the lives of adolescents/ young people permeated by restructuring and learning. Motherhood changing their perceptions of the world and competing with social experiences in this phase of life, such as wanting to leave and living more intensely with partners. However, some refer that motherhood led them to learn to have more responsibility and to put their child's needs before their own. Thus, they aim to work and/or "have a future", which in turn favors the motivation to live, to adhere to medications and "to be healthy" to raise their children. For others, it eases the burdens of life, in this case, the fact of living with HIV meaning as a disease.

Being a mother, even being a new mother like that [...] you become a mature person you know, you think differently. [...] leaving everything behind is difficult, new right, wants to go out, wants to have friends [...] you have your son, there, being healthy, being well, you having what to give him eat, for him to wear, you're fine. It doesn't matter if you don't have it for you, I think that's it. (P1)

Pregnancy teaches a lot, not giving up on life [...] motivates us more. (P5)

My children brought motivation to live more life, to have more happiness, even because of the disease, because then you don't think so much either. You know that for you to be able to raise your children you have to be able to be healthy. (P3)

Pregnancy also served as a self-affirmation for one of the young women, in the sense that she could have a child if she wanted to.
Ibrought a lot of learning, [...] to take care of myself, to know and learn that I could have a child, yes, if I want to. (P8)

As for life projects, some participants intended to finish their studies and/or go to college, mostly aiming to get a job with stability to offer the best for their children's future.

Studies [...] my life goal now is to form her future, to have stability so that I can give what she wants. (P1)

Unlike what they experienced with their families, most participants plan to talk to their children and support them so that they understand what HIV is, know how to experience sexuality, being better able to make oriented decisions and come to adopt behaviors preventive measures against Sexually Transmitted Infections (STIs) and unwanted pregnancies.

I think for her a different life than mine, that she understands, knows things, that I can be together, because my mother was not, maybe that's why I didn't have this support, being able to talk and explain things to her, explain about pregnancy. (P8)

I intend to talk, when she has her period, I will start to explain. I'll even make a list of questions to explain to her. (P9)

As for reproductive desire, only three young people were still thinking about having another child and one planned to adopt. The rest were satisfied with the current number of children.

\section{DISCUSSION}

It can be said that most participants did not have access to reproductive planning during their health monitoring. It is a programmatic and individual vulnerability in caring for adolescents/young people who were born infected with HIV, which denotes the late search for health services. They do not know they were pregnant or start to think about this possibility only when some signs are evident, such as period delay and nausea. This suggests a possible lack of knowledge about their body and a weak awareness about the relationship between the exercise of sexuality and reproductive possibilities, corroborating the study with adult women in Sweden ${ }^{(12)}$. This experience of "surprise" or little critical perception about the possibility of being pregnant suggests not prior reflection in relation to about the decision to generate, or not, a new being, either through preventive conducts for contraception or even for the non-infection of the partners. It is noteworthy that due to the serological condition, adolescents/ young people are followed up in a specialized service. However, focusing on clinical and therapeutic evaluation, including adherence, but this population, for the most part, does not have follow-up in PHC services, generally responsible development evaluation and reproductive planning.

When pregnancy occurs without having been planned and without having been the object of action in the course of health care, it becomes more complex to legitimize it. Conceiving a child in the context of HIV seropositivity can be an emotionally difficult experience for women ${ }^{(12)}$. It has a special connotation in adolescence, since it is a phase of life in which personal identity 
is still being constituted from contact with the various discourses throughout socialization processes since childhood, which are actively recreated, transforming their world psychosocial and social life. Thus, their daily life is loaded with meanings and interpretations of cultural norms, myths and forms of knowledge $\mathrm{e}^{(9)}$.

Finding a pregnancy in the context of HIV seropositivity - in which, in previous assistance experience, this possibility has not been minimally addressed as a source of reflection and resulting conduct - seems to be potentially more capable of producing negative repercussions on maternal and child health. It also encourages adolescents/young people to consider terminating pregnancy through induced abortion, even though if this practice is illegal in Brazil. However, the consideration of this hypothesis needs to be understood from the elements that may imply in this decision, such as specific moments in the life cycle added to plans for the future, forms of family organization and partnership, and the social and family context in which this pregnancy occurs.

Previous negative family experiences in living with HIV favor the feeling of distrust and the difficulty of believing in a different outcome than VT. In this sense, they need to face fears and uncertainties, especially involving the risk to the baby's health and to their own, due to the possibility of not being able to maintain pregnancy and/or their illness, corroborating other studies $^{(13-14)}$. A study points out that orphans of the HIV epidemic live with a chronic condition, need health and emotional care ${ }^{(15)}$ to overcome possible limitations related to living with HIV, such as stigma, adherence to medication and experience of sexuality.

A study carried out in southern Brazil with women with HIV points out that abortion rates are higher compared to the general population, which suggests a precarious access to information and effective methods of contraception, despite the strong investment in the use policy of the condom ${ }^{(16)}$. Guaranteeing reproductive rights in the context of HIV seropositivity needs to be expanded beyond the investment in reducing VT, towards comprehensiveness, including ensuring access to educational actions, reproductive planning, assisted reproduction, effective contraceptive methods and inputs.

Positive reaction of the partner to the pregnancy contributes to the reduction of emotional overload for the adolescent/young person and to make her feel more prepared to have a child. A study with adolescents not infected with HIV in the state of Paraíba, Brazil points out that partners accept pregnancy, but report facing psychological, social and economic challenges because it is a fact that changes several facets of daily life ${ }^{(17)}$, entailing responsibilities, expenditure of time, expenses and energy for baby care. On the other hand, family members blame themselves for a possible mistake, considering that the plans or projects of life they had for the adolescent/young person went through other paths. It corroborates with studies that affirm that these feelings can be transformed, or not, in acceptance and support, depending on how the family understands pregnancy ${ }^{(17)}$. It is noteworthy that there is vulnerability to receiving social support for pregnancy in adolescence, and the presence of this support is essential for adequate acceptance of motherhood.

Discontent with the way of delivery forwarded by health professionals denotes a situation of vulnerability to access to information and choice about the type of delivery resulting from a violation of rights that can occur since prenatal care (or since reproductive planning when this occurs) due to the lack of dialogue with the adolescent/young person to investigate their knowledge and desires as to possible ways of delivery, the pros and cons, to make an informed and informed decision. However, this violation can also result from a lack of sensitivity, welcoming and active listening during delivery care in health services. Recognizing human rights presupposes the reciprocal recognition of people's prerogatives and duties as free and equal members of a certain community ${ }^{(18)}$. Health professionals often embody the right to information and have the opportunity to articulate an informed decision to the person's daily life, respecting their autonomy.

Feelings of fear, guilt, anxiety and concern regarding the child's exposure to HIV occur in a situation of vulnerability to adherence to VT prophylaxis, and need to be balanced by the spirit of trust, relief and positive expectations regarding the non-confirmation of the diagnosis of infection. The concern with the possibility of VT seems to contribute to a personal implication of women to "do everything that is right", from prenatal care until after birth. A study carried out in São Paulo, points out that the act of generating a seronegative child provides women with a brief sensation of completeness, as they fulfill their "mission"(4), and express the feeling of "duty accomplished", pointing out good adherence to HIV VT prophylaxis.

There is a concern with the repercussion of the disease in the future relationship with the child and with the child's reactions to the maternal and personal diagnosis (when applicable). Together, these findings demonstrate a relevant peculiarity of the experience of motherhood in the presence of HIV, which can emotionally burden women ${ }^{(13)}$. Evidence of factors that interfere with VT supports the importance of early identification of HIV-infected pregnant women and their active search for permanent clinical and laboratory evaluation and implementation of prophylactic and support measures ${ }^{(19)}$. Many pregnant women still fail to perform anti-HIV testing during prenatal care or do not undergo VT prophylaxis, often due to lack of information. It is noteworthy that VT confirmation has repercussions on maternal mental health and on the relationship with the baby ${ }^{(13)}$.

Motherhood has the potential to produce pleasurable emotions in the face of adversity, to provide a new meaning for life, relief for anxieties and for the other effects of HIV and its treatment ${ }^{(13)}$, helping, therefore, in the constitution of projects of happiness. In the performance of the maternal role, the fear of not surviving or not having the minimum health conditions to care for the child for long enough, integrates this experience, being also observed in the daily lives of mothers not infected with $\mathrm{HIV}^{(20)}$, although of not so pronounced. Moreover, it is evident that children can be considered a motivating factor for adherence to treatment and the main reason for these women to take care of themselves ${ }^{(13)}$.

A study in Thailand points out that, often, having a child appears as proof that the mother could have prevented her VT infection $^{(18)}$. In this sense, the existence of antiretroviral therapy is the main argument of some women to justify making the decision to become pregnant and overcoming fear of VT viable, as identified in a study in Sweden ${ }^{(12)}$. Therefore, this technical advance assists in deconstructing the belief of not being able to be a mother, due to HIV, allowing motherhood to emerge in her 
conception, and that of health professionals, as a woman's right, regardless of the serological condition, as objectively should be.

Adolescents/young people who were born infected with HIV because they currently have the possibility of greater survival, start to experience experiences similar to those not infected by the virus and are faced with issues related to unpreparedness and resentment with the loss of youth ${ }^{(21)}$, the continuity of the study, professionalization, entry, permanence and rise in the labor market. A study conducted with adult women in Rio de Janeiro corroborates these findings and points out that living with HIV did not change the concept of what it means to be a mother, on the contrary, the motherhood process would be a good experience and is similar to that of any woman ${ }^{(22)}$.

The reports of plans for future dialogues on sexuality with their children express the efforts of the participants to "do different" than their own experiences denoted by silence in relation to the theme; yearn to be more open with their children. This desire must count on the presence of instrumentalized and reflective health professionals to assist in approaching the topic in a close and dialogical way, not limited only to the prevention of STIs and pregnancy, according to a study conducted with mothers of adolescents in the state of Rio Grande do Sul, Brazil(23).

Although surrounded by ambiguities and fears, the family poses itself as a significant instance ${ }^{(24)}$ for the understanding of life projects of adolescents/young people. The expression of doubts elucidates that HIV competes with some of his dreams and plans, tolerating them or making them impossible. Thus, some think about the possibility of adoption, which denotes another future issue: the disclosure of the parents' diagnosis to their adopted children ${ }^{(25)}$.

\section{Study limitations}

As a limitation, it is considered to have been performed in a single service in the municipality, which can also denote its specificities. Information indicates questions for other investigations and can serve as a subsidy for the improvement of public actions and policies, serving as a guidance tool for implantations in the health system.

\section{Contributions to the area of nursing, health, and public policies}

There is a need to reorganize the services to qualify the health care model and configure it as care that promotes comprehensive health protection as a counterpoint to the situation of vulnerability to an unplanned pregnancy. It takes place in a context of insufficient access to information, to dialogue in preventive and clinical guidelines and to the relevant resources and technologies for risk reduction and promotion of maternal and child health in the face of an ongoing pregnancy and motherhood. The technical-scientific discussion about pregnancy and motherhood contributes to minimize the practices of prejudice and discrimination and aims to provide services for the construction of a comprehensive care proposal, with clearer dialogues between professionals and adolescents/young people. It also minimizes difficulties and individual, programmatic and social barriers, mainly through access to information, respect for citizenship, and the promotion of the right to health.

\section{FINAL CONSIDERATIONS}

It is understood that the experience of pregnancy and motherhood by adolescents/young people who were born infected with HIV results from occurrence of ambivalent feelings regarding the discovery of the ongoing pregnancy in the context of their seropositivity. The news of the pregnancy is received by the partner with joy, by the relatives, with a certain concern and by the health professionals of the specialized service, with care for the prenatal care. In the experience of childbirth, the woman's desire was sometimes disregarded, resulting in the violation of rights to information and choice. They fulfill VT prophylaxis with concern and fear, when they discover their children's HIV seronegativity they mention relief and a sense of accomplishment. Effective motherhood has implications for their life stories and projects for the future, they wish to resume their studies, work, establish stable affective bonds and start a family. It is evident that, unlike the silence in the family/social space that occurred in their trajectories in relation to sexuality, there is the planning of future dialogues on the topic with their children.

In general, the experience of pregnancy and motherhood by adolescents/young people who were born infected with HIV does not differ from other HIV-infected women who become pregnant, in relation to ambivalent feelings, concerns about their health and that of their children, and care regarding prophylaxis. The unprecedented finding of this study refers to the implications for life stories and projects for the future, since while adolescents/young people, at the time of most pregnancies, and young people, at the time of the interviews, aim to experience relationships and the context of improving their lives. life and, especially, in relation to the desire and plans for dialogues with their children about sexuality and prevention of diseases/infections and unwanted pregnancies.

The results of this study suggest that there are different experiences of motherhood and that, at least for a group of young mothers, motherhood is a life experience full of positive meanings, even though fears and insecurities are simultaneously experienced. The study contributed to coping with vulnerability to the occurrence of unplanned pregnancy, pointing out the need for dialogical proposals that respect human rights in the production of comprehensive care and contemplating reproductive planning.

It is understood that everyone has the right to well-being and to the full development of their abilities and that it is necessary to establish adequate living conditions for all. Many of the concerns of society in general regarding the health of the adolescent/youth and their child are recognized as legitimate. However, it is also understood that the negative and reductionist conception about the "problem" of pregnancy/maternity in adolescence can build restrictions and conceptual implications in the development of research and in the performance of health professionals with adolescents/young people.

\section{FUNDING}

The present study was carried out with support from the Coordination of Higher Education Personnel Improvement (Coordenação de Aperfeiçoamento de Pessoal de Nível Superior, abbreviated CAPES) - Financing Code 001. 


\section{REFERENCES}

1. Mindry D, Wanyenze RK, Woldetsadik MA, Finocchario-Kessler S, Goggin K, Wagner G. Safer conception for couples affected by HIV: structural and cultural considerations in the delivery of safer conception care in Uganda. AIDS Behav. 2017;21(8):2488-96. doi: 10.1007/s10461-017-1816-4

2. Ministério da Saúde (BR). Secretaria de Vigilância em Saúde. Departamento de Doenças de Condições Crônicas e Infecções Sexualmente Transmissíveis. Protocolo Clínico e Diretrizes Terapêuticas para Prevenção da Transmissão Vertical do HIV, Sífilis e Hepatites Virais. Brasília (DF): Ministério da Saúde; 2019. 248 p.

3. Zihlmann KF, Alvarenga AT. What is this desire? Reproductive decisions among women living with HIV/Aids from a psychoanalysis perspective. Saúde Soc. 2015;24(2):633-45. doi: 10.1590/S0104-12902015000200019

4. Silva CB, Motta MGC, Bellenzani R. Motherhood and HIV: reproductive desire, ambivalent feelings and a/an (not) offered care. Rev Bras Enferm. 2019;72(5):1378-88. doi: 10.1590/0034-7167-2018-0063

5. Oliveira GM, Carvalho MFAA, Teixeira MA, Coelho EAC, Araújo RT. Percepção de mulheres soropositivas para o hiv sobre direitos Reprodutivos. Rev Enferm UFPE. 2016;10(8):3028-5. doi: 10.5205/reuol.9373-82134-1-RV1008201630

6. Oliveira GM, Carvalho MFAA, Teixeira MA Costa LD, Cura CC, Perondi AR, França VF, Bortoloti DS. Epidemiological profile of high-risk pregnant women. Cogitare Enferm. 2016;21(2):1-8. Available from: https://revistas.ufpr.br/cogitare/article/view/44192/28238

7. Zanelatto R, Cabral CS, Barbosa RM, Peres SV. Biografias e contextos: especificidades da iniciação sexual de jovens vivendo com HIV infectadas por transmissão vertical. Sexualid Salud Soc. 2018;(30):224-41. doi: 10.1590/1984-6487.sess.2018.30.11.a

8. Ministério da Saúde (BR). Secretaria de Vigilância em Saúde, Departamento de Vigilância, Prevenção e Controle das Infecções Sexualmente Transmissíveis, do HIV/Aids e das Hepatites Virais. Boletim Epidemiológico HIV/AIDS. N Especial - 2019. Brasília: Ministério da Saúde, 2019.72 p.

9. Paiva VSF. Dimensão Psicossocial do Cuidado. In: Paiva VSF; Ayres JR; Buchalla CM. (Orgs.). Coletânea: Vulnerabilidade e Direitos Humanos. Prevenção e Promoção da Saúde: Da doença à cidadania. V. II (pp. 41-72). Curitiba, PR: Juruá Editora. 2012.

10. Lira DMB, Silva RCA. Adolescência: quando surgiu e para onde vai? um recorte histórico e psicossocial. Rev Latino-Am Psicol Corp. 2017;4(6):42-52. Available from: https://psicorporal.emnuvens.com.br/rlapc/article/view/54/85

11. Minayo CSM. O desafio do conhecimento: pesquisa qualitativa em saúde. 13. ed., São Paulo: Hucitec, 2013.

12. Carlsson-Lalloo E, Berg M, Mellgren A, Rusner M. Sexuality and childbearing as it is experienced by women living with HIV in Sweden: a lifeworld phenomenological study. Int J Qual Stud Health Well-being. 2018; 13(1): 1487760. doi: 10.1080/17482631.2018.1487760

13. Levandowski DC, Canavarro MC, Pereira MD, Maia GN, Schuck LM, Sanches IR. Maternidade e HIV: revisão da literatura brasileira (20002014). Arq Bras Psicol. 2017;69(2):34-51. Available from: http://pepsic.bvsalud.org/pdf/arbp/v69n2/04.pdf

14. Camillo SO, Silva LO, Cortes JM, Maiorino FT. O desejo de ser mãe com a infecção por HIV/AIDS. R Enferm Cent O Min. 2015;5(1):1439-56. DOI: http://dx.doi.org/10.19175/recom.v0i0.552

15. Apolinario ASAC, Antunes MC. Adoção de crianças e adolescentes soropositivos. Bol Acad Paul Psicol [Internet]. 2015 [cited 2019 Jan 5];35(89):325-49. Available from: http://pepsic.bvsalud.org/pdf/bapp/v35n89/v35n89a06.pdf

16. Pilecco FB, Teixeira LB, Vigo A, Knauth DR. Post-diagnosis abortion in women living with HIV/Aids in the south of Brazil. Ciênc saúde coletiva. 2015;20(5):1521-30. DOI: http://dx.doi.org/10.1590/1413-81232015205.13002014

17. Monteiro e Oliveira LF, Davim RMB, Alves ESRC, Rodrigues ESRCR, Nóbrega MF, Torquato JA. Pregnancy and childbirth experience of adolescent recent mothers. Rev Enferm UFPE. 2016;10(2):395-406. doi: 10.5205/1981-8963-v10i2a10969p395-406-2016

18. Liamputtong P, Haritavorn N. My life as Mae Tid Chua Mothers who contracted HIV disease: motherhood and women living with HIV/AIDS in central Thailand. Midwifery. 2014;30(12):1166-72. doi: 10.1016/j.midw.2014.04.003

19. Potty RS, Sinha A, Sethumadhavan R, Isac S, Washington R. Incidence, prevalence and associated factors of mother-to-child transmission of HIV, among children exposed to maternal HIV, in Belgaum district, Karnataka, India. BMC Public Health. 2019;19(1):386. doi: 10.1186/s12889-019-6707-3

20. Beltrame GR, Donelli TMS. Maternidade e carreira: desafios frente à conciliação de papéis. Aletheia [Internet], 2012 [cited 2019 Jan 5];3839:206-17. Available from: http://pepsic.bvsalud.org/pdf/aletheia/n38-39/n38-39a17.pdf

21. Correia SR, Silva JMO, Santos AAP, Comassetto I, Lima GKS, Ferreira SCS. Nursing care to adolescent woman in labor in the light of Wanda Horta's theory. Rev Pesqui: Cuid Fundam. 2017;9(3):857-66. doi: 10.9789/2175-5361.2017.v9i3.857-866

22. Spindola T, Dantas KTB, Cadavez NFV, Fonte VRF, Oliveira DC. Maternity perception by pregnant women living with HIV. Invest Educ Enferm. 2015;33(3):440-8. doi: 10.17533/udea.iee.v33n3a07

23. Savegnago SDO, Arpini DM. A abordagem do tema sexualidade no contexto familiar: o ponto de vista de mães de adolescentes. Psicol Cien Prof. 2016;36(1):130-44. doi: 10.1590/1982-3703001252014

24. Eid AP, Weber JLA, Pizzinato A. Maternidade e projetos vitais em jovens infectadas com HIV por transmissão vertical. Rev Latino-Am Cienc Soc Niñez Juv. 2015;13(2):937-50. Available from: http://revistaumanizales.cinde.org.co/rlcsnj/index.php/Revista-Latinoamericana/article/view/1978/595

25. Zanon BP, Paula CC, Padoin SMM. Revelação do diagnóstico de HIV para crianças e adolescentes: subsídios para prática assistencial. Rev Gaúcha Enferm. 2016;37(esp):e2016-0040. doi: 10.1590/1983-1447.2016.esp.2016-0040 